\title{
Zaaien en vooral de akker bewerken voordat men kan oogsten
}

\section{Naar een integrale en laagdrempelige toegang tot het sociale domein}

\author{
Hardy van de Ven · Roland Blonk
}

Published online: 31 October 2018

(c) Bohn Stafleu van Loghum is een imprint van Springer Media B.V., onderdeel van Springer Nature 2018

Het gemeentelijke sociale domein is enorm in beweging. Op Walcheren hebben gemeentelijke uitvoerings- en welzijnsorganisaties een nieuwe werkwijze ontwikkeld van maatwerk in de zorg en participatiebevordering ten behoeve van cliënten. Een maatkostuum, mits goed gemaakt, past gemiddeld beter dan confectie, zo is de gedachte. In dit artikel wordt uitgelegd hoe in het Entryproject agile projectmanagementoplossingen biedt voor de vertaling van maatwerk in een integrale benadering en laagdrempelige toegang tot het sociale domein. En dat binnen een politieke en bij herhaling veranderende context.

\section{Het Entry-project}

Het doel van het Entry-project was om op een Walcheren wijkgebonden integrale en laagdrempelige toegang tot het sociale domein te ontwikkelen. Dat wil zeggen toegang tot alle organisaties, diensten en voorzieningen die mensen ondersteunen om hun leefbaarheid en participatie te bevorderen - de zogenaamde éénloketgedachte. De totstandkoming van één toegang vraagt veel van betrokken organisaties. Zo'n toegang betekent in de praktijk het ontschotten van de eigen organisatie, het herzien van de samenwerking met andere partijen en een andere manier van werken, met een bejegening waarin de klant centraal staat in plaats van gestandaardiseerde werkprocessen. Op Walcheren is één organisatie verantwoordelijk voor de

\author{
H. van de Ven $(\triangle) \cdot$ R. Blonk \\ TNO, Leiden, Nederland \\ hardy.vandeven@tno.nl \\ R. Blonk \\ Tilburg School of Social and Behavioral Sciences, \\ Universiteit Tilburg, Tilburg, Nederland
}

North-West University, Potchefstroom, Zuid-Afrika uitvoering van de Participatiewet (werk, inkomen en schuldhulpverlening). Een andere organisatie is verantwoordelijk voor maatschappelijke ondersteuning (welzijn, zorg, opvoeden en groeien). Met deze twee organisaties is het door de EU gefinancierde Entryproject gestart met een specifieke organisatieveranderingsfilosofie, namelijk sociale innovatie in combinatie met agile projectmanagement (APM).

\section{Agile projectmanagement}

APM is afkomstig uit de wereld van de softwareontwikkeling en wordt steeds vaker ingezet in andere disciplines om innovatie te bevorderen [1]. APM is een manier van bottom-up ontwikkelen om de gevraagde transformatie in manier van werken, controle en professionele vaardigheden te bereiken. Hierin staat de visie van de professional centraal en wordt vandaaruit gekeken welke organisatie nodig is om die visie te faciliteren. APM geeft zodoende handen en voeten aan sociale innovatie, namelijk het tegelijk sleutelen aan de cultuur en structuur van de organisatie, om zowel de dienstverlening te verbeteren als een gezonde en uitdagende werkomgeving te creëren. Een ontwikkelteam bestaande uit professionals van beide organisaties is met APM-principes aan de slag gegaan: het in korte loops ontwikkelen van werkprocessen en instrumenten ten behoeve van het loket. Concreet betekent dit zo snel mogelijk werkbare halfproducten (bijvoorbeeld vragenlijsten en procedures) testen in de praktijk en iteratief doorontwikkelen. De verwachting is dat APM beter past bij innovatie in het sociale domein dan traditioneel projectmanagement, waar eerst een verregaand eindproduct wordt ontwikkeld alvorens dit in de praktijk te testen. Door het gebruik van korte ontwikkel-loops kan sneller ingespeeld worden op een continu, vaak politiek ingegeven, veranderende context. 


\section{Een turbulente projectstart}

Een voorbeeld van een continu veranderende context is dat in het sociale domein bij herhaling partnerorganisaties ontstaan, fuseren of reorganiseren. In de Walcherse situatie was dit niet anders. Tussen het indienen van het projectplan en het starten van het Entryproject (zo'n anderhalf jaar) werd de nieuwe organisatie voor de uitvoering van de Wmo opgericht. Deze organisatie was in de eerste anderhalf jaar van het project vooral bezig met het vanuit een top-downvisie toekomstbestendig maken van de organisatie. Logischerwijs was er weinig animo om net ingerichte werkprocessen te herzien. Daarnaast kampten zowel de 'Wmo-organisatie' als de 'Participatieorganisatie', vergeleken met zusterorganisaties, met een klein personeelsbestand. Dit bemoeilijkte de inzet van personeel in het project, ondanks de EU-middelen. De ontwikkeling van de éénloketgedachte werd daardoor gedomineerd door een discussie die voornamelijk ging over het mogelijke eindresultaat en de interferentie met huidige bestuurlijke kwesties, zienswijzen en financiering. Vooral het aspect van de organisatiestructuur van sociale innovatie kreeg daarmee aandacht, waarbij (bedrijfs)culturele aspecten werden verwaarloosd. Het resultaat was dat de APM-principes aanvankelijk niet uit de verf kwamen. APM vraagt juist om experimenteerruimte, waarin praktische toepasbaarheid en resultaat belangrijker zijn dan bestaande bestuurlijke processen.

\section{Experimenteerruimte versus bestuurlijke con- trole}

Bovenstaand voorbeeld geeft aan dat APM zoals gebruikt bij softwareontwikkeling niet een-op-een is toe te passen bij innovatie in het sociale domein. De oplossing werd gevonden door het management meer te betrekken bij de ontwikkeling, dat wil zeggen mee te laten denken in een vroeger stadium van iteraties. Daardoor ontstond eerder acceptatie door het management voor het testen van nieuwe producten. Het testen van nieuwe producten bevorderde ook de uitwisseling en samenwerking tussen de professionals. Daarmee kregen de culturele aspecten van sociale innovatie meer aandacht. Uiteindelijk heeft dit geresulteerd in een compromis waarin de gedachte aan één loket per wijk werd losgelaten ten faveure van één handelwijze bij de verschillende uitvoeringsorganisaties. Eén handelwijze zou de onderlinge communicatie tussen professionals van de organisaties vergemakkelijken. Voor deze handelwijze zijn vervolgens meerdere instrumenten ontwikkeld ten behoeve van het integraal uitvragen. Zo worden mensen met een zorggerelateerde vraag uitgebreider bevraagd over hun inkomen, eventuele schulden en werk (of mogelijkheden daartoe). Anderzijds worden mensen met een inkomensvraag nu ook in het zorgdomein bevraagd. Van één fysiek loket per wijk naar één handelwijze op verschillende plaatsen, terwijl de ontwikkelde instrumenten ook gemakkelijk in een wijkgerichte opzet zouden kunnen worden ingezet.

\section{Voorwaarden voor APM in het sociale domein}

Sociale innovatie met gebruik van APM is een van de vele ontwerpfilosofieën voor organisatieverandering. We pretenderen niet dat dit dé manier is om maatwerk in het sociale domein te bewerkstelligen, maar wel een aanpak die oplossingen biedt voor het omgaan met een turbulente omgeving. Voorwaarde is een juiste balans tussen bottom-upexperimenteerruimte en bestuurlijke controle. Bij die experimenteerruimte horen ook het (financieel) vrijmaken van professionals om de nieuwe oplossingen voor maatwerk te ontwikkelen en het aandacht besteden aan culturele verschillen tussen organisaties. Vooral het overwinnen van culturele verschillen kost tijd. Weliswaar is de oorspronkelijke éénloketgedachte losgelaten, maar er is wel een integrale wijze van uitvragen ontwikkeld die onafhankelijk is van de inrichting van de organisatie. Daarnaast is het wederzijdse begrip van en voor organisatieprocedures toegenomen. Zo zien we momenteel meerdere initiatieven ontstaan in lijn met het gedachtegoed van een integrale werkwijze, waarbij de via het project opgedane kennis wordt ingezet. Daarbij gaat het er om te zaaien en vooral de akker te bewerken, voordat men kan oogsten.

\section{Literatuur}

1. BeckK, Beedle M, Bennekum Avan, etal. Manifesto for agile software development. Caryton: Agile Alliance; 2001. 